\title{
Perbandingan Tingkat Kepuasan Kerja Perawat dan Kepuasan Pasien
}

\section{Comparison of Nurse's Job Satisfaction Level and Patient's Satisfaction Level}

\author{
Jamilla Upik Noras* Ratu Ayu Dewi Sartika**
}

\begin{abstract}
*Bagian Pendidikan dan Penelitian Rumah Sakit Umum Pemerintah Fatmawati, **Departemen Gizi Kesehatan Masyarakat Fakultas
\end{abstract} Kesehatan Masyarakat Universitas Indonesia

\begin{abstract}
Abstrak
Perawat adalah ujung tombak pemberi pelayanan langsung pada pasien selama 24 jam. Tujuan penelitian adalah untuk membandingkan tingkat kepuasan kerja perawat dengan kepuasan pasien terhadap pelayanan keperawatan kelas 3 di Rumah Sakit Umum Pusat (RSUP) X Jakarta. Penelitian ini bersifat deskriptif dengan desain studi cross sectional, pendekatan kuantitatif dan kualitatif. Populasi adalah seluruh perawat yang bertugas sebagai pelaksana keperawatan kelas 3 sebanyak 40 orang serta pasien yang dirawat di ruang rawat inap kelas 3 sebanyak 120 orang. Pengambilan sampel dilakukan secara purposive sampling sesuai dengan kriteria inklusi dan ekslusi. Hasil pengukuran kuantitatif menunjukkan bahwa tingkat kepuasan kerja perawat pelaksana di kelas 3 dikategorikan "rendah", $(22,5 \%)$ sedangkan tingkat kepuasan pasien terhadap layanan keperawatan sebesar $85,0 \%$ (nilai $p>0,05$ ). Ketidakpuasan kerja perawat yang tinggi tidak berdampak pada kepuasan pasien terhadap pelayanan keperawatan. Untuk perbaikan ketidakpuasan kerja perawat, manajemen rumah sakit sebaiknya meninjau kembali kebijakan tentang pakaian dinas, menu makanan pada saat jaga, dan merancang kamar ganti perawat. Selain itu, perlu dilakukan perhitungan jasa pelayanan perawat dengan memperhatikan risiko keterpaparan terhadap penyakit. Supervisor diharapkan dapat lebih membuka diri untuk mendengarkan masalah yang dihadapi perawat pelaksana melalui komunikasi dan hubungan interpersonal secara informal.
\end{abstract}

Kata kunci: Kepuasan kerja perawat, kepuasan pasien, rawat inap, kelas tiga

\section{Abstract}

Nurses are front liner in providing nursing services directly to customers for 24 hours. The purpose of this study was to compare the level of job satisfaction of nurses to patient satisfaction in the third class departement in general hospital of Jakarta. This study was a cross sectional study designed with quantitative and qualitative approaches. The study population was all nurses who served as executive nurses (40 nurses) and patients treated in the inpatient (120 patients). Sampling was conducted purposively according to inclusion and exclusion criteria. The results of quantitative measurements showed that the level of job satisfaction of nurses categorized as "low" $(22,5 \%)$, while the level of patient satisfaction on nursing service at $85,0 \%$ ( $p$ value $>0,05$ ). The high job dissatisfaction of nurses had no impact on patient satisfaction. To decrease the job dissatisfaction of nurses, hospital management should review the policy on official clothing, meals at the guard, and design the locker room of nurses. It also performed the calculation of nursing services with the risk of exposure to disease and supervisors more open to listen the problems faced by nurses with communication and informal interpersonal relationships.

Key words: nurse's job satisfaction, patient satisfaction, inpatient, the third class.

\section{Pendahuluan}

Rumah Sakit Umum Pusat (RSUP) X merupakan rumah sakit pendidikan dengan jumlah perawat pada bulan April tahun 2010 sekitar 36,75\%. Peraturan Menteri Kesehatan Republik Indonesia Nomor 340/MenKes/PER/III/2010 menentukan perbandingan perawat dengan pasien adalah 1 berbanding 2.1 Sementara di rumah sakit ini, rasio perawat pelaksana dengan pasien adalah 1 berbanding 6 . Hal ini menunjukkan beban kerja perawat yang tinggi dalam memberikan pelayanan keperawatan khususnya di ruang rawat inap. Rasio tenaga perawat pelaksana yang belum sesuai ditambah lagi dengan perawat yang mengajukan

Alamat Korespondensi: Ratu Ayu Dewi Sartika, Departemen Gizi Kesehatan Masyarakat FKM Universitas Indonesia, Gd. F Lt. 2 Kampus Baru UI Depok 16424, Hp.08568470670,e-mail: ayu_fkm_ui@yahoo.com 
pindah ke institusi lain menyebabkan beban kerja perawat menjadi lebih berat.

Heskett dalam Tjiptono, ${ }^{2}$ mengemukakan keterkaitan erat antara kepuasan karyawan dan kepuasan pelanggan. Kepuasan karyawan didapatkan dari desain pekerjaan dan tempat kerja yang memfasilitasi kualitas layanan internal. Karyawan yang puas berpeluang untuk loyal dan meningkatkan produktivitas kerja. Peningkatan produktivitas yang diikuti dengan ketulusan dalam membantu pelanggan akan menghasilkan nilai layanan eksternal. Studi awal tentang kepuasan kerja perawat pelaksana secara kualitatif menunjukkan bahwa kepuasan kerja perawat masih belum optimal terutama dalam pengembangan karir. Penilaian kepuasan pasien yang dilaksanakan oleh Instalasi Pemasaran dan Humas (IPH) tahun 2007 dan 2008 menunjukkan rata-rata skor sebesar 7,47 dan 7,77.3

Kepuasan kerja adalah suatu perasaan positif tentang pekerjaan seseorang yang merupakan hasil dari sebuah evaluasi karakteristiknya. Seseorang dengan tingkat kepuasan kerja yang tinggi memiliki perasaan positif tentang pekerjaan tersebut, sedangkan seseorang yang tidak puas memiliki perasaan negatif tentang pekerjaan tersebut. ${ }^{4}$ Menurut Gibson, ${ }^{5}$ kepuasan kerja didefinisikan sebagai sikap yang dimiliki para pekerja tentang pekerjaan mereka. Hal tersebut merupakan hasil dari persepsi mereka tentang pekerjaan. Kepuasan kerja merupakan respon afektif atau emosional terhadap berbagai segi atau aspek pekerjaan seseorang sehingga kepuasan kerja bukan merupakan konsep tunggal. Seseorang dapat relatif puas dengan salah satu aspek pekerjaan dan tidak puas dengan satu atau lebih aspek lainnya.

Tujuan penelitian adalah mengetahui tingkat kepuasan kerja perawat pelaksana dan dampak pada pelayanan keperawatan kepada pasien dengan melihat tingkat kepuasan pasien selama mendapatkan layanan keperawatan menggunakan 5 dimensi mutu.

\section{Metode}

Penelitian deskriptif ini menggunakan rancangan cross sectional dengan pendekatan kuantitatif dan kualitatif. Populasi adalah seluruh perawat yang bertugas sebagai pelaksana keperawatan di kelas 3 yang berjumlah 40 orang serta 120 pasien yang dirawat di ruang rawat inap kelas 3. Pengambilan sampel dilakukan secara purposive sampling sesuai dengan kriteria inklusi dan eksklusi meliputi pasien rawat inap kelas 3 yang telah dirawat minimal selama 3 hari dan dapat berkomunikasi dengan baik. Kriteria eksklusi yang ditetapkan adalah pasien yang tidak bersedia menjadi responden atau tidak bersedia menjawab pertanyaan penelitian. Informan dalam penelitian kualitatif adalah perawat yang bekerja di ruang rawat inap kelas 3 dan melakukan layanan keperawatan bagi pasien yang menjadi responden dalam stu- di kuantitatif.

Mula-mula dilakukan pengukuran secara kuantitatif terhadap kepuasan pasien dan perawat. Setelah itu, dilanjutkan pengukuran secara kualitatif yang bertujuan untuk membandingkan antara tingkat kepuasan kerja perawat dengan tingkat kepuasan pasien terhadap pelayanan keperawatan dengan mengeksplorasi lebih dalam antara kenyataan dan harapan pada kepuasan kerja perawat dengan apa yang menjadi harapan menurut informan.

Instrumen pengumpulan data berupa kuesioner tentang 5 dimensi mutu yang meliputi tangible, reliability, responsiveness, assurance, dan emphaty. Analisis data kualitatif meliputi telaah dokumen dan transkrip yaitu menerjemahkan dan menelaah data dari hasil wawancara, membuat matriks rangkuman inti dan pernyataanpernyataan, melakukan klarifikasi hasil berdasarkan isi (content analysis), menyajikan data informasi yang tersusun, dan melakukan verifikasi substansi (triangulasi substantif).

\section{Hasil}

Pada Tabel 1 menunjukkan kepuasan kerja perawat ruang rawat inap berdasarkan persentase tingkat pemenuhan harapan kepuasan kerja berdasarkan 5 dimensi mutu. Rata-rata tingkat kepuasan total perawat adalah $73,78 \%$. Berdasarkan 5 dimensi kepuasan, dimensi responsiveness memperlihatkan rata-rata yang lebih tinggi sekitar 80,56\% dibandingkan dengan dimensi kepuasan yang lain. Skor terendah terlihat pada dimensi tangible sekitar 63,89\%. Tingkat kepuasan kerja perawat dan kepuasan pasien dikelompokkan menjadi puas dan tidak puas dengan menggunakan cut off point 90,0\% (Tabel 2 dan 3). Sebagian besar perawat merasa tidak puas pada dimensi tangible, reliability, assurance, dan merasa puas pada dimensi responsiveness. Secara total sekitar 77,5\% perawat merasa tidak puas dalam bekerja sebagai perawat pelaksana (Tabel 2).

Semua dimensi kepuasan pasien memiliki skor tingkat pemenuhan harapan yang hampir sama. Skor tertinggi pada dimensi assurance (98,95\%) sedangkan terendah pada dimensi responsiveness $(96,28 \%)$. Rata-rata tingkat kepuasan total pasien sebesar 97,18\% (Tabel 4).

Tabel 1. Skor Tingkat Pemenuhan Harapan Kepuasan Kerja Perawat Kelas 3 di RSUP X Jakarta

\begin{tabular}{lcccc}
\hline Dimensi Kepuasan & Rata-rata & SD & Minimal & Maksimal \\
\hline Tangible & 0,6389 & 0,16236 & 0,30 & 1,00 \\
Reliability & 0,7140 & 0,15606 & 0,32 & 1,01 \\
Responsiveness & 0,8056 & 0,12932 & 0,43 & 1,00 \\
Emphaty & 0,7827 & 0,10898 & 0,52 & 1,00 \\
Assurance & 0,7500 & 0,15326 & 0,40 & 1,00 \\
\hline Kepuasan total & $\mathbf{0 , 7 3 7 8}$ & $\mathbf{0 , 1 1 4 6 4}$ & $\mathbf{0 , 4 7}$ & $\mathbf{0 , 9 6}$ \\
\hline
\end{tabular}


Tabel 2. Gambaran Tingkat Kepuasan Kerja Perawat Kelas 3 di RSUP X Jakarta

\begin{tabular}{llll}
\hline Dimensi Mutu & Kategori & Jumlah & $\%$ \\
\hline Tangible & Tidak puas & 35 & 87,5 \\
Reliability & Puas & 5 & 12,5 \\
Responsiveness & Tidak puas & 28 & 70,0 \\
& Puas & 12 & 30,0 \\
Empathy & Tidak puas & 16 & 40,0 \\
& Puas & 24 & 60,0 \\
Assurance & Tidak puas & 20 & 50,0 \\
& Puas & 20 & 50,0 \\
Kepuasan total & Tidak puas & 22 & 55,0 \\
& Puas & 18 & 45,0 \\
\hline
\end{tabular}

Tabel 3. Gambaran Tingkat Kepuasan Pasien Kelas 3 di RSUP X Jakarta

\begin{tabular}{llll}
\hline Dimensi Mutu & Kategori & Jumlah & $\%$ \\
\hline Tangible & Tidak puas & 15 & 12,5 \\
Reliability & Puas & 105 & 87,5 \\
& Tidak puas & 20 & 16,7 \\
Responsiveness & Puas & 100 & 83,3 \\
& Tidak puas & 21 & 17,5 \\
Empathy & Puas & 99 & 82,5 \\
Assurance & Tidak puas & 16 & 13,3 \\
& Puas & 104 & 86,7 \\
& Tidak puas & 14 & 11,7 \\
Kepuasan total & Puas & 106 & 88,3 \\
\hline & Tidak puas & $\mathbf{1 8}$ & $\mathbf{1 5 , 0}$ \\
& Puas & $\mathbf{1 0 2}$ & $\mathbf{8 5 , 0}$ \\
\hline
\end{tabular}

Tabel 4. Skor Tingkat Pemenuhan Harapan Kepuasan Pasien Kelas 3 di RSUP X Jakarta

\begin{tabular}{lcccc}
\hline Dimensi Kepuasan & Rata-rata & SD & Minimal & Maksimal \\
\hline Tangible & 0,9654 & 0,11862 & 0,67 & 1,29 \\
Reliability & 0,9832 & 0,12949 & 0,60 & 1,17 \\
Responsiveness & 0,9628 & 0,15416 & 0,50 & 1,17 \\
Emphaty & 0,9873 & 0,13977 & 0,64 & 1,20 \\
Assurance & 0,9895 & 0,14262 & 0,64 & 1,15 \\
\hline Kepuasan total & $\mathbf{0 , 9 7 1 8}$ & $\mathbf{0 , 1 3 0 3 5}$ & $\mathbf{0 , 5 0}$ & $\mathbf{1 , 1 7}$
\end{tabular}

Tabel 5. Karakteristik Informan

\begin{tabular}{llll}
\hline Informan & Jenis Kelamin & Pendidikan & Kode \\
\hline Perawat & Perempuan & D3 Keperawatan & A, B, C \\
Pasien lantai IV & Perempuan & SMP & D, E \\
Pasien lantai V & Laki-laki & SMP, SMA & F, G \\
Pasien lantai VI & Laki-laki & SMA, SD & H, I \\
\hline
\end{tabular}

Sebagian besar pasien merasa puas pada kelima dimensi mutu. Proporsi puas tertinggi terdapat pada dimensi tangible $(87,5 \%)$ dan terendah pada dimensi responsiveness $(82,5 \%)$. Proporsi kepuasan total pasien sebesar $85,0 \%$. Hasil analisis bivariat menunjukkan tidak ada hubungan antara kepuasan kerja perawat dengan kepuasan pasien dalam menerima pelayanan keperawatan (nilai $\mathrm{p}>0$,05) (Tabel 4).

Hasil wawancara mendalam diperoleh dari informan yang terdiri dari 3 orang perawat dan 6 orang pasien (Tabel 5). Perawat yang dipilih sebagai informan adalah perawat yang bertugas pada ruang perawatan pasien kelas 3 yang menjadi responden dalam penelitian kuantitatif.

\section{Kepuasan Kerja Perawat}

Secara keseluruhan, kepuasan kerja perawat terutama terhadap fasilitas, sarana dan prasarana dalam menjalankan tugas pelayanan keperawatan serta dukungan atasan langsung masih tergolong kurang. Selain itu, hubungan interpersonal dengan atasan langsung sedikit formal dan tidak terbuka. Terdapat informan yang merasa kurang puas terhadap fasilitas dan sarana prasarana, tetapi mendapat dukungan dan puas terhadap hubungan timbal balik dengan atasan langsung.

"Kurang puas terhadap kepuasan kerja karena fasilitas, sarana prasarana yang diperlukan untuk mendukung pekerjaan kurang diperhatikan, cukup puas dengan dukungan dan hubungan yang baik dengan atasan langsung" (A).

"Kurang puas terutama terhadapa sarana prasarana, serta dukungan yang kurang dari atasan langsung, hubungan interpersonal sedikit formal” (B, C).

\section{Kepuasan Pasien}

Pasien di ruang rawat secara umum menyatakan sudah puas dengan pelayanan yang diberikan oleh perawat di ruang perawatan, walaupun masih ada kekurangan tetapi sudah dapat memenuhi harapan.

"Sudah puas dengan pelayanan yang diberikan oleh perawat, perawatnya baik dan perhatian, saya bersyukur sudah dapat dibantu dalam penyembuhan penyakit" (D, E, F, G, H, I).

\section{Kebijakan Organisasi}

Kebijakan organisasi adalah segala sesuatu yang berhubungan dengan ketentuan rumah sakit tentang penggajian, fasilitas, sarana dan prasarana, kesempatan berkembang, mendapatkan penghargaan, serta peningkatan karir. Hampir seluruh informan menyatakan bahwa fasilitas kamar ganti, toilet, serta sarana dalam memberikan pelayanan keperawatan kepada pasien kurang memadai. Sementara kesempatan berkembang tenaga perawat disesuaikan dengan peraturan yang berlaku, seluruh perawat mempunyai kesempatan untuk mengembangkan karir.

"Saya kan PNS jadi gaji sesuai dengan pangkat/golongan, sedangkan untuk uang jasa pelayanan untuk perawat seharusnya diberikan lebih karena risiko terpa- 
par penyakit menular lebih besar" (A, C).

"Kalau bagi saya yang non PNS penghasilan yang diberikan sudah cukup memadai" (B).

"Untuk pakaian seragan dinas sebenarnya kurang cuma dikasih satu stel, kalau udah pudar ya buat sendiri. Untuk makanan jaga malam yang diberikan membosankan, jadi kalau ingin yang lain beli sendiri" (A, B, C).

"Saat ini kamar ganti dan toilet yang dipakai kurang memadai" (A, B).

"Ruang ganti dan toilet untuk perawat tidak terlalu memadai belum lagi kalau mahasiswa keperawatan yang praktek disini ikutan numpang jadi kurang nyaman" $(\mathrm{C})$.

"Kepala ruangan memberikan kesempatan yang sama untuk kita mengikuti pelatihan yang diperlukan, disesuaikan dengan jadwal dinas agar pelayanan tidak terganggu. Sedangkan kesempatan untuk mengikuti pendidikan yang lebih tinggi ada peraturannya jadi sesuai dengan aturan yang ada” (A, B ,C).

"Alat bantu dalam memberikan asuhan keperawatan bahan habis pakai seperti kapas, perban, alkohol, hand scoon, dan lain-lain sudah cukup terpenuhi. Untuk perlengkapan mandi pasien seperti washlap masih kurang" (A, B).

"Alat bantu dalam memberikan asuhan keperawatan bahan habis pakai cukup tersedia, tetapi untuk perlengkapan mandi masih kurang, jadi pasien saya sarankan untuk membawa sendiri" (C).

"Semua diberikan kesempatan yang sama untuk mengikuti pelatihan dengan pengaturan jadwal dinas. Untuk mengikuti pendidikan disesuaikan dengan peraturan yang ada” (A, B, C).

\section{Tuntutan Tugas}

Tugas memberikan pelayanan keperawatan dijalankan sesuai dengan standar dan prosedur yang digunakan di rumah sakit. Perawat pelaksana berperilaku baik kepada pasien dalam menjalankan pelayanan keperawatan untuk membantu proses penyembuhan pasien.

"Keterampilan khusus perlu dimiliki oleh seorang perawat dalam memberikan pelayanan kepada pasien, keterampilan dapat diperoleh pada saat kuliah dan mengikuti pelatihan-pelatihan" (A, B, C).

"Standar dan prosedur pelayanan keperawatan dapat dengan mudah untuk dilihat dan diketahui karena tersusun dalam satu folder yang ada di meja perawat" (A, B, C).

"Asuhan keperawatan diberikan sesuai dengan kondisi pasien memberikan pelayanan dengan sopan dan ramah, supaya pasien cepat sehat kembali" (A, B).

"Asuhan keperawatan diberikan sesuai dengan kondisi pasien memotivasi pasien untuk kesembuhannya, membuat pasien merasa nyaman dengan pelayanan yang diterima" $(\mathrm{C})$.

\section{Pengawasan}

Pengawasan yang dilakukan pada perawat pelaksana bertujuan agar pelayanan keperawatan berjalan sesuai dengan standar dan prosedur yang berlaku. Menurut informan, atasan langsung seharusnya memberikan dukungan dan mencarikan jalan keluar jika menemukan masalah dalam memberikan pelayanan keperawatan kepada pasien.

"Atasan langsung selalu memberikan dukungan kepada kami, selalu ada kesempatan berdiskusi. Jika menemukan masalah atasan langsung saya bersedia membantu dan mencarikan jalan keluar, saya senang karena kami saling mendukung sehingga masalah dapat teratasi” (A).

"Ada dukungan dari atasan langsung dalam memberikan pelayanan, kadang-kadang berdiskusi kalau ada waktu. Jika menemukan masalah tidak langsung dicarikan jalan keluarnya tetapi tetap disalahkan" (B, C).

"Belum pernah ada yang bermasalah dan diberikan sanksi” (A, B, C).

\section{Interaksi Sosial}

Terdapat kesempatan melakukan interaksi sosial formal maupun informal, baik berhubungan dengan atasan langsung maupun kerja sama dengan rekan kerja. Hal ini dapat dilakukan selama jam kerja berlangsung. Menurut informan, interaksi dengan atasan langsung dapat dilakukan secara formal dan informal, begitu pula interaksi dengan sesama rekan kerja (perawat lain) sehingga setiap permasalahan yang ditemui dapat langsung dipecahkan secara terbuka dan bersama-sama.

"Hubungan dengan atasan langsung dengan perawat pelaksana sangat akrab tidak harus formal, kalau ada masalah langsung disampaikan, ibu terbuka terhadap masalah yang ada"(A).

"Hubungan dengan atasan langsung biasa saja hanya dekat dengan orang tertentu, interaksi kadang berlangsung formal, kalau ada masalah ditulis pada buku laporan” (B, C).

\section{Kompetensi Perawat}

Kompetensi perawat meliputi menghormati hak privasi klien/pasien, menjamin kerahasian dan keamanan informasi tentang status kesehatan klien, serta menghormati hak pasien untuk memperoleh informasi. Menurut informan, perawat pelaksana telah melakukan semua hal tersebut.

"Perawat disini menghormati dan menghargai pasien, memberikan penjelasan mengenai kesehatan serta menjaga rahasia mengenai penyakit pasien” (A, B, C).

“...cukup sesuai dengan kompetensinya” (D, E, F). 


\section{Komunikasi Perawat}

Pelayanan keperawatan yang diberikan melibatkan hubungan interpersonal antara perawat dan pasien yang dilakukan selama 24 jam. Oleh sebab itu, diperlukan komunikasi yang baik antara perawat dan pasien. Menurut informan, perawat pelaksana dapat diajak berkomunikasi dengan baik, mau menyapa, dan memberikan semangat bagi pasien dan keluarga pasien. Perawat melayani pasien dan keluarga pasien dengan ramah dan sopan.

"Perawat disini melayani kami dan keluarga dengan ramah, kadang-kadang dapat diajak berkeluh kesah, serta memberikan semangat kepada kami dan keluarga" (D, E, F).

"Kalau ingin dilayani lebih, jangan dirawat disini, ini kan rumah sakit pemerintah jadi sesuai dengan bayaran, kalau perawat sedang sibuk jangan tanya-tanya dulu” (G).

"Perawat disini ramah dan santun walau mereka sibuk apalagi kalau pasien banyak, tetapi masih dapat mengajak kami berkomunikasi” (H).

"Perawat disini mau mendengarkan keluh kesah $\mathrm{ka}$ mi dan menanggapi dengan baik” (G, H, I).

"Kalau perawatnya tidak sibuk mereka mendengarkan keluh kesah kami dan menanggapi dengan baik" (H, I).

\section{Penjelasan tentang Kondisi, Pengobatan, dan Perawatan}

Informasi yang diberikan oleh perawat tentang kondisi pasien, proses pengobatan, dan asuhan keperawatan sudah sesuai dengan batasan kewenangan perawat. Penjelasan yang diberikan mudah dimengerti dan dipahami oleh pasien dan keluarga sehingga dapat mengetahui kondisi penyakit pasien.

"Pada awal dirawat disini perawat menyampaikan hal-hal yang berhubungan dengan kondisi kesehatan saya, proses pengobatan yang akan saya jalani dan pelayanan perawatan yang akan diberikan dengan jelas" (D, E).

"Saya masih harus bertanya mengenai kondisi kesehatan saya dan pengobatan selanjutnya, perawat akan menjelaskan dengan jelas setelah ditanyakan.” (G, H, I)

"Penjelasan perawat cukup jelas, tapi harus ada keluarga saya yang ikut mendengarkan.” (F)

"Informasi yang disampaikan perawat mudah untuk saya pahami." (D, E, F)

\section{Sarana dan Prasarana}

Ruang perawatan yang bersih, nyaman, tenang, dan tersedia toilet yang bersih dengan air yang cukup merupakan hal yang diperlukan pasien selama menjalani proses perawatan di rumah sakit. Demikian pula dengan penampilan perawat yang bersih dan rapi serta kebersihan peralatan yang digunakan dalam asuhan keperawatan seperti washlap, sarung tangan, dan lain lain membuat pasien me- rasa senang dan nyaman menerima pelayanan.

"Ruang perawatan cukup bersih walau sedikit gerah (panas), kamar mandi airnya cukup kadang-kadang bersih, pada saat jam besuk saja agak sedikit ramai. Kalau perawat penampilannya bersih dan rapih” (D, E).

"Kalau ingin mengikuti keinginan kondisi ruangan tidak nyaman dan gerah (panas), kondisi toilet cukup bersih ada air tersedia, saya bersyukur walau di kelas 3 tetapi penampilan perawatnya bersih dan rapih" (D, E, F, $\mathrm{G}, \mathrm{H}, \mathrm{I})$.

"Untuk peralatan yang digunakan seperti kapas, perban, sarung tangan plastik, selalu baru tidak ada yang bekas, kecuali washlap yang digunakan untuk membasuh pasien itu nggak baru”(A, B, C).

"Untuk peralatan kapas, perban, sarung tangan, dan lain-lain selalu baru tidak ada yang bekas, kalau washlap untuk perlengkapan mandi kami dianjurkan untuk menyediakan sendiri”(E, F).

\section{Pembahasan}

\section{Tingkat Kepuasan Kerja Perawat}

Hasil penelitian menunjukkan bahwa tingkat kepuasan total kerja perawat kelas 3 di RSUP X sebesar $73,78 \%$. Jika dibandingkan dengan standar nilai pembanding harapan dan kenyataan sebesar 90\% maka dapat dikatakan bahwa sebagian besar perawat kelas 3 di RSUP $\mathrm{X}$ tidak puas terhadap pekerjaan yang dilakukan sebagai perawat pelaksana $(77,5 \%) .{ }^{3}$ Upaya perbaikan terhadap nilai pemenuhan kepuasan kerja perawat terdapat pada dimensi tangible yaitu tersedianya fasilitas untuk perawat seperti pakaian kerja, makanan/minuman untuk jaga malam di tempat kerja, fasilitas ruang ganti perawat, serta tersedia kamar mandi bersih dan air yang cukup.

Kondisi tersebut diakui oleh perawat yang mengatakan bahwa seragam perawat hanya diberikan satu pasang setiap tahun dan jika sudah pudar/rusak maka perawat membuatnya sendiri, padahal terdapat beberapa jenis seragam dalam seminggu. Fasilitas lain seperti kamar ganti perawat merupakan ruangan biasa yang dialihfungsikan menjadi kamar ganti sehingga tidak memadai untuk melakukan ganti pakaian. Kiranya perlu dikaji ulang mengenai kebijakan dalam memberikan seragam dinas untuk perawat, makanan untuk jaga, serta kamar ganti khusus perawat sesuai dengan fungsinya sehingga perawat merasa lebih nyaman.

Secara keseluruhan, rata-rata persentase pemenuhan kepuasan kerja perawat pada dimensi tangible terkait dengan kebijakan rumah sakit sebesar 63,89\%. Kebijakan merupakan salah satu faktor yang dapat menimbulkan ketidakpuasan kerja (faktor higiene/dissatisfiers). Untuk mengurangi ketidakpuasan kerja perawat pelaksana di ruang rawat inap, perlu dilakukan perbaikan pada faktor higiene terutama kebijakan dalam penyediaan fasilitas untuk perawat seperti pakaian kerja, 
makanan/minuman untuk jaga malam, serta kebijakan merancang kamar ganti perawat. Namun, perbaikan pada faktor higiene hanya dapat mengurangi ketidakpuasan tetapi tidak dapat meningkatkan kepuasan karena faktor higiene bukan merupakan sumber kepuasan. ${ }^{6}$

Pada dimensi reliability dan assurance diperoleh hasil sebanyak $70,0 \%$ dan $55 \%$, perawat merasa tidak puas terutama pada penghasilan, status/pengakuan, serta kehandalan atasan langsung dalam membantu mencarikan solusi dalam pemecahan masalah. Hal ini diakui oleh perawat bahwa penghasilan yang dimaksud adalah jasa pelayanan yang diberikan untuk perawat seharusnya lebih besar karena mereka memiliki risiko tinggi untuk tertular penyakit sedangkan dalam hal dukungan atasan langsung hanya 1 orang perawat yang mengatakan kepala ruangan mempunyai waktu yang cukup dalam mengatasi segala permasalahan yang ada.

Perbaikan yang diperlukan untuk meningkatkan kepuasan kerja perawat dalam hal risiko tertular penyakit dapat diperhitungkan dengan menambahkan score penghitungan jasa pelayanan bagi perawat berdasarkan ruang perawatan dan tingkat risikonya. ${ }^{7,8}$ Untuk mengetahui dukungan yang diharapkan perawat pelaksana terhadap atasan langsung dapat dilakukan komunikasi informal kepada atasan langsung. Menurut Fecikova, ${ }^{7}$ ketidakpuasan kerja dapat disebabkan aturan atau batasan yang ditetapkan dan diberlakukan oleh manajemen pada kegiatan pekerjaan di setiap unit yang dapat berdampak pada kepuasan kerja.

Rata-rata persentase pemenuhan kepuasan kerja perawat pada dimensi responsiveness dan emphaty sebesar $80,56 \%$ dan $78,27 \%$. Hal yang perlu diperbaiki pada kedua dimensi ini adalah atasan langsung perlu memberikan pujian kepada pelaksana yang telah memberikan pelayanan dengan baik kepada pelanggan, perlunya diberlakukan pemberian sanksi yang dinyatakan salah dalam memberikan layanan, serta atasan langsung yang selalu bersikap adil dalam menetapkan keputusan. ${ }^{7}$

Individu akan merasa puas atau tidak puas tergantung dari adanya keseimbangan. Perasaan keseimbangan dan ketidakseimbangan atas suatu situasi yang diperoleh individu dengan cara membandingkannya dengan orang lain. Hasil penelitian pada dimensi responsiveness dan emphaty menunjukkan bahwa perawat pelaksana mempunyai harapan yang tinggi terhadap keseimbangan dalam mendapatkan dukungan dari atasan langsung.

Menurut Benner et al, ${ }^{9}$ faktor kepuasan kerja perawat meliputi pengakuan, potensi pengembangan, serta lingkungan kerja yang menyenangkan. Sumber ketidakpuasan kerja antara lain komunikasi yang buruk, peraturan, kebijakan yang tidak jelas, serta tekanan yang tidak pada tempatnya. ${ }^{7}$ Untuk itu, perlu ditingkatkan kepuasan kerja perawat dengan cara memperbaiki faktor yang menyebabkan ketidakpuasan perawat serta meningkatkan faktor kepuasan kerja perawat. Perawat mempunyai andil besar terhadap proses timbulnya kepuasan pasien. ${ }^{10}$

\section{Tingkat Kepuasan Pasien}

Sebagian besar pasien kelas 3 adalah pasien tidak mampu atau pasien dengan pembiayaan program jaminan kesehatan masyarakat (jamkesmas). Salah satu kebijakan di rumah sakit tersebut adalah memberikan pelayanan yang bermutu bagi seluruh pasien termasuk pasien tidak mampu.

Hasil penilaian pasien terhadap pelayanan keperawatan di kelas 3 menunjukkan bahwa sebagian besar pasien merasa puas dengan pelayanan keperawatan yang diterima $(97,18 \%)$. Kepuasan klien merupakan suatu tanggapan emosional terhadap pengalaman mengonsumsi suatu produk atau jasa. Kepuasan klien atau pasien adalah tingkat keadaan yang dirasakan seseorang yang merupakan hasil dari membandingkan penampilan atau outcome produk yang dirasakan dalam hubungannya dengan harapan seseorang. ${ }^{11}$ Kepuasan klien dalam industri jasa pelayanan kesehatan merupakan respon terhadap penilaian klien atas jasa pelayanan yang diterimanya. Respon klien terhadap jasa pelayanan yang diterima sangat menentukan kelangsungan organisasi yang bergerak di bidang pelayanan jasa seperti institusi rumah sakit. ${ }^{3}$

Jika dilihat dari seluruh pernyataan dengan nilai tertinggi didapatkan pernyataan yang terkait dengan pelayanan perawat kepada pasien. Hal ini sesuai dengan pasien sebagai informan yang menyatakan bahwa perawat selalu berpakaian bersih dan rapi, bersedia mendengarkan keluhan mereka, dan menanggapi dengan baik. Jika dilihat berdasarkan elemen kepuasan pasien seperti sikap caring perawat, kompetensi perawat, komunikasi perawat yang efektif, dan sikap penghargaan perawat terhadap pasien maka elemen-elemen tersebut telah terpenuhi sesuai dengan pernyataan yang disampaikan oleh pasien. Perawat sebagai tenaga kesehatan dituntut untuk meningkatkan mutu pelayanan dengan menyesuaikan antara mutu pelayanan yang dihasilkan dengan harapan klien. Apabila pelayanan yang diterima sesuai dengan harapan maka klien sebagai pasien akan puas dan jika melebihi harapan maka klien akan sangat puas, demikian pula sebaliknya. ${ }^{3}$ Dengan demikian tampak bahwa harapan klien memiliki peran yang besar sebagai standar perbandingan dalam evaluasi kualitas pelayanan melalui kepuasan klien.

Secara keseluruhan, sebagian besar pasien $(85,0 \%)$ menyatakan puas terhadap pelayanan keperawatan. Kepuasan pasien didapat dari harapan terhadap mutu pelayanan yang diterima pasien. Harapan pasien tersebut terdiri dari beberapa aspek meliputi kemudahan dalam mengakses atau mendapatkan perawatan, tenaga keseha- 
tan yang kompeten dan terampil, pengobatan yang sesuai, tenaga kesehatan memberikan penjelasan tentang kondisi dan pengobatan/perawatan yang diberikan, sikap tenaga kesehatan yang menghargai pasien, sikap tenaga kesehatan yang penuh perhatian, sikap tenaga kesehatan yang profesional, serta kondisi pasien menjadi lebih baik setelah mendapatkan perawatan. ${ }^{12,13}$

\section{Perbandingan Tingkat Kepuasan}

Kepuasan kerja perawat dan kepuasan pasien merupakan bagian dari indikator dalam menilai mutu pelayanan kesehatan/keperawatan. Kepuasan klien dalam industri jasa pelayanan kesehatan merupakan respon terhadap penilaian klien atas jasa pelayanan yang diterima. Respon klien terhadap jasa pelayanan yang diterima sangat menentukan kelangsungan organisasi yang bergerak di bidang pelayanan jasa. ${ }^{3}$

Dilihat dari 5 dimensi mutu, tingkat kepuasan kerja perawat dinilai masih rendah tetapi pasien merasa puas terhadap pelayanan keperawatan yang diterima. Hasil penelitian ini menunjukkan walaupun tingkat kepuasan kerja perawat rendah tetapi perawat tetap memberikan pelayanan keperawatan sesuai dengan kompetensi, keterampilan, dan melakukan asuhan keperawatan sesuai dengan prosedur. Hal ini dapat dijadikan contoh bagi petugas kesehatan lain yang bekerja dalam memberikan layanan keperawatan di rumah sakit dan unit layanan kesehatan lain sehingga harapan pasien mendapatkan pelayanan keperawatan dapat terpenuhi.

Tidak ada hubungan antara kepuasan kerja perawat dengan kepuasan pasien. Hal ini didukung oleh hasil kualitatif yang ditunjukkan oleh pernyataan informan yang puas terhadap pelayanan keperawatan yang diberikan oleh perawat seperti perawatnya baik dan penuh perhatian sehingga pasien merasa sangat terbantu dalam proses penyembuhan. Menurut perawat, walaupun kepuasan kerja perawat kurang, tetapi dalam memberikan pelayanan keperawatan kepada pasien tetap mengutamakan kesembuhan pasien, melayani dengan sopan dan ramah, memberikan asuhan keperawatan sesuai dengan kondisi pasien, dan memotivasi pasien untuk sehat kembali. Harapan perawat tidak memengaruhi dan mengurangi tanggung jawab moral perawat dalam melakukan pekerjaannya sebagai perawat pelaksana.

Jika karyawan tidak puas dengan pekerjaan yang diberikan maka karyawan tersebut tidak mampu memberikan pelayanan dengan baik dalam meningkatkan kepuasan pasien. Terdapat keterkaitan erat antara kepuasan karyawan dan kepuasan pasien. ${ }^{2}$ Hasil penelitian ini menunjukkan bahwa ketidakpuasan kerja perawat tidak menyebabkan pasien tidak puas terhadap pelayanan yang diberikan, tetapi menyebabkan beberapa perawat pindah kerja ke institusi lain atau mengundurkan diri. ${ }^{9}$

\section{Kesimpulan}

Tingkat kepuasan kerja perawat pelaksana di kelas 3 RSUP X Jakarta dikategorikan rendah $(22,5 \%)$ sedangkan tingkat kepuasan pasien terhadap layanan keperawatan sebesar $85,0 \%$ (nilai $\mathrm{p}>0,05$ ). Ketidakpuasan kerja perawat tidak berdampak pada kepuasan pasien terhadap pelayanan keperawatan.

\section{Saran}

Untuk perbaikan ketidakpuasan kerja perawat sebaiknya manajemen rumah sakit meninjau kembali kebijakan tentang pakaian dinas, menu makanan pada saat jaga, dan rancangan untuk kamar ganti perawat. Selain itu juga, dilakukan perhitungan jasa pelayanan perawat dengan memperhatikan risiko keterpaparan terhadap penyakit dan atasan langsung perawat pelaksana lebih membuka diri untuk mendengarkan masalah yang dihadapi perawat pelaksana dengan cara komunikasi dan hubungan interpersonal secara informal.

\section{Daftar Pustaka}

1. Jati SP. Beberapa konsep dasar tentang konsep manajemen rumah sakit. 2007 [diakses tanggal 12 April 2010]. Diunduh dari: http://scribd.com/doc/10911297/Nambah.

2. Tjiptono, Fandy, Gregorius C. Service quality and satisfaction. Yogyakarta: Andi Publisher; 2008.

3. Supranto. Pengukuran tingkat kepuasan pelanggan: untuk menaikkan pangsa pasar. Jakarta: PT Rineka Cipta; 2001.

4. Robbin SP. Perilaku organisasi. 2nd ed. Jakarta: Penerbit Salemba Empat; 2007.

5. Gibson JL. Organisasi dan manajemen perilaku, struktur, proses. Edisi Keempat. Jakarta: Erlangga; 2000.

6. Ting-Yueh C, Shun-Ching H. Conceptualizing and measuring experience quality: the customer's perspective. The Service Industries Journal. 2010; 30 (14): 2401-19.

7. Fecikova I. An index method for measurement of customer satisfaction. The TQM Magazine. 2004; 16 (1): 57-66.

8. Castle NG. An instrument to measure job satisfaction of nursing home administrators. BMC Medical Research Methodology. 2006; 6 (47): 111.

9. Benner P, Sheets V, Uris P, Mallocha K, Schwed K, Jamison D. Individual, practice, and system causes of errors in nursing. The Journal of Nursing Administration. 2002; 32 (10): 509-23.

10. Hsia T, Lin L, Wu J, Tsai HA. Framework for designing nursing knowledge management systems. Interdisciplinary Journal of Information, Knowledge, Management. 2006; 1: 13-21.

11. Wijono D. Manajemen mutu pelayanan kesehatan: teori, strategi, dan aplikasi. Surabaya: Universitas Airlangga Press; 2000.

12. Baumgartner, Grant D, Hamilton A. Internal audit: consider the implications, healthcare financial management. Academic Research Library. 2004; 58 (6):34.

13. Joiner TA. Total quality management and performance: the role of organization support and co-worker support. International Journal of Quality and Reliability Management. 2007; 24: 617-27. 